Ireneusz Milewski (Gdańsk)

\title{
The ECONOMic Condition of The Bishopric of GAZA (Palestine) during the Rule of Bishop Porphyry (CIRCA 395-420)*
}

ot much is known about property owned by bishoprics in Late Antiquity
outside of $\mathrm{Egypt}^{1}$, be it in the Western or the Eastern provinces of the Empire. Due to the lack of concrete data concerning the property owned (including real estate and buildings of various uses) or cash reserves, a rough idea of the size of the relevant financial assets may be inferred from information on the scale of the charities run by individual bishoprics (i.e. the sums of money mentioned at such occasions), the donations received, as well as residual data concerning the economical operations undertaken, including leased property. The latter information is rather scarce; and in view of its laconic nature, even the little that we do have leaves much to be desired. This also applies to the cases that will be addressed below, where we shall attempt to describe the financial condition of a small provincial bishopric, namely the church in Gaza (Palestine) during the rule of bishop Porphyry (395420 AD). All of the information on the subject comes from the Vita Porphyrii, a source whose historical value has often been disputed. Despite the unequivocal title, the text is not a typical hagiographic work: in the version in which we know it today, it is more of a record of bishop Porphyry's struggle against pagans in Gaza ${ }^{2}$. Only in passing, it seems - while describing the consecutive stages of the disputes

\footnotetext{
* This article was written with the financial support of the Polish National Science Centre (UMO2015/17/B/HS3/00135).

${ }^{1}$ As a matter of fact, the literature on Church property in early Byzantine Egypt is so extensive that it is hardly possible to list even the most important works here; cf., among others, E. WIPSZYCKA, Les ressources et les activités économiques des églises en Égypte du IVe au VIII siècle, Bruxelles 1972 [= PapB, 10]; J. GAscou, Les grands domaines, la cité et l'état en Egypte byzantine. (Recherches d'histoire agraire, fiscale et administrative), TM 9, 1985, p. 1-90; R. BAGNAL, Egypt in Late Antiquity, Princeton 1995.

${ }^{2}$ A.H.M. Jones, The Later Roman Empire, 284-602. A Social, Economic and Administrative Survey, vol. II, Oxford 1964, p. 345, 943, 994; G. Fowden, Bishops and Temples in the Eastern Roman Empire AD 320-435, JTS 29, 1978, p. 53sqq; C. Rapp, Mark the Deacon, Life of St. Porphyry of Gaza, [in:] Medieval Hagiography. An Anthology, ed. T. HeAd, New York-London 2001, p. 55.
} 
- does Mark the Deacon make certain observations shedding some light on the economic standing of the bishopric. The analysis of those accounts will be the subject of the present study.

First, however, a few remarks on the Vita Porphyrii and its author are in order. Little is known about Mark the Deacon; all information about him comes from his work. As he himself assures us, he came from Asia and was a calligrapher by profession. In the early 390s, as a pious pilgrim, Mark reaches Palestine and settles down in Jerusalem, where he meets Porphyry. The latter was probably ordained priest there in 392, by bishop John (in the Vita replaced by Praylios, his Orthodox substitute). At that point, the lives of both personae of The Life become intertwined, so that Mark will accompany his bishop - as a participant of the events described - until his mentor's death in $420 \mathrm{AD}^{3}$. Already in $395 \mathrm{AD}$, however, Mark is ordained deacon and follows his bishop to his new seat in Gaza ${ }^{4}$. Mark the Deacon claims that he was an eyewitness of the events he describes; nonetheless, such assurances are frequent in hagiographic works.

As was mentioned above, The Life is not a typical hagiographic work; besides, in view of its numerous problems, it belongs to the most controversial early Byzantine sources. Some of the difficulties are connected with the chronology of the work's origin (as well as the location where it was written down); others relate to the anachronisms that appear in $\mathrm{it}^{5}$. In the version known to us today, it constitutes, most of all, a narrative of the clashes between the Christians and the pagans in Gaza at the turn of the $4^{\text {th }}$ and $5^{\text {th }}$ centuries. Such a statement is indeed justified, since the text is dominated by descriptions of Gaza and the religious conflicts in the city ${ }^{6}$. The Vita Porphyrii bears traces of later thorough redactions, probably in the middle of the $6^{\text {th }}$ century ${ }^{7}$. It is worth mentioning that, apart from the Greek version of The Life used in the research on the history of the late Empire,

\footnotetext{
${ }^{3}$ Marc le Diacre, Vie de Porphyre, évêque de Gaza, 103, trans. H. Grégoire, M.-A. Kugener, Paris 1930 [= CB] (cetera: Marcus Diaconus, Vita Porphyrii). For comments on the authorship of the Vita Porphyrii and the time of its creation, cf. recently T.D. BARnes, Early Christian Hagiography and Roman History, Tübingen 2010, p. 260-284, who argues for a $6^{\text {th }}$-century date for the Greek text of the Vita. Cf. also F.R. Trombley, Hellenic Religion and Christianization, c. 370-529, vol. I, Leiden-New York 1993, p. 246sqq. See also the comments in the two latest editions of the Vita: Marcus DiacoNUs, Vita Sancti Porphyrii = Leben des heiligen Porphyrius, trans. A. HüBner, Freiburg im Breisgau 2013 [ = FCh, 53], p. 7sqq and La conversion de Gaza au christianisme. La Vie de S. Porphyre de Gaza par Marc le Diacre (BHG 1570), ed. et trans. A. LAMPADARIDI, Bruxelles 2016 [= SHa, 95], p. 12sqq. ${ }^{4}$ Marcus Diaconus, Vita Porphyrii, 17-18. Cf. also O. Nicholson, R. Durmaz, Porphyry of Gaza, [in:] The Oxford Dictionary of Late Antiquity, vol. II, ed. O. Nicholson, Oxford 2018, p. 1211.

${ }^{5}$ K.G. Holum, Theodosian Empresses. Women and Imperial Dominion in Late Antiquity, BerkeleyLondon 1982, p. 55.

${ }^{6}$ Я.М. Чехановец, Marnas victus est a Christo. К вопросу о христианизации древней Газы, [in:] МНЕМОН. Исследования и публикаиии по истории античного мира, V, ed. Э.Д. Фролов, Санкт-Петербург 2006, p. 419sqq.

${ }^{7}$ Cf. P. Mayerson, Justinians's Novella 103 and the Reorganisation of Palestine, BASOR 269, 1988, p. 65sqq.
} 
a Georgian version (probably based on a Syriac one) is also extant ${ }^{8}$, as is a still unpublished Slavonic one. In terms of historical value, they do not differ from the Greek version, which will constitute the basis for the findings presented below.

Thus, let us proceed to discussing the main issue at hand, i.e. the size of the assets held by the bishopric of Gaza under Porphyry's rule.

\section{The property of the bishopric of Gaza: real estate}

In the Vita Porphyrii, Mark the Deacon mentions property in possession of the church of Gaza on two occasions. At the turn of the $5^{\text {th }}$ century AD, the city was pagan $^{9}$, as were most towns in the East at the time. Local Christians, if we are to believe Mark's account, only counted 280 souls at the moment of bishop Porphyry's arrival in Gaza (circa $395 \mathrm{AD}$ ) ${ }^{10}$. According to the statistic presented by the author in a later part of the text (the credibility of which I doubt), the city had barely over 400 inhabitants at the point when the pagan shrines were destroyed (the event may be dated to the late spring of $404 \mathrm{AD}$ based on the clues given by Mark). Thus, unfortunately, we have practically no reliable information to determine the number of inhabitants at the turn of the $5^{\text {th }}$ century AD, when Porphyry was the bishop of the city ${ }^{11}$. Still, it is clear that the Christian community of the town was sparse, and as such probably reflected the typical proportion in the towns of the Roman East at the time. As we learn from Mark the Deacon's account, the bishopric of Gaza owned property managed by means of lease, also to local pagans.

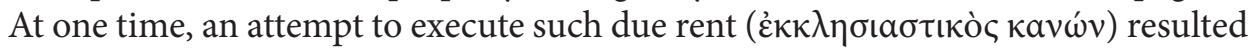
in the battery of deacon Barochas, who had been sent to collect the money - he served in the church of Gaza as a steward (treasurer) ${ }^{12}$ at that time. The incident led to an upheaval in the town after Barochas, beaten unconscious and presumed dead by the pagans, was taken into the city by the Christians ${ }^{13}$. Here, the thread

\footnotetext{
${ }^{8}$ On the Georgian version of the Vita Porphyrii see P. Peeters, La vie géorgienne de saint Porphyre de Gaza, AB 59, 1941, p. 165-216 (introduction, commentary and Georgian text with Latin translation). ${ }^{9}$ F.R. Trombley, Hellenic..., p. 246 sqq; ffv

${ }^{10}$ Marcus Diaconus, Vita Porphyrii, 19. Cf. also C. Rapp, Mark..., p. 54; J. Hahn, Die Herausforderung der antiken Stadt in der Spätantike - Christentum, urbane Sakraltopographie und religiöse Gewalt, [in:] Pluralität. Konkurrenz. Konflikt Religiöse Spannungen im städtischen Raum der Vormoderne, ed. J. OBERste, Regensburg 2013 [= FM.S, 8], p. 11-30.

${ }^{11}$ For some estimates of the number of inhabitants of Gaza in the Roman and early Byzantine period, cf. M. Broshi, The Population of Western Palestine in the Roman-Byzantine Period, BASOR 236, 1979, p. 5; L. SEGnI, The Territory of Gaza. Notes of Historical Geography, [in:] Christian Gaza in Late Antiquity, ed. B. Bitton-Ashkelony, A. Kofsky, Leiden-Boston 2004 [= JSRC, 3], p. 41sqq.

${ }^{12}$ Marcus Diaconus, Vita Porphyrii, 22.

${ }^{13} \mathrm{Cf}$. M. Blume, La Vie de Porphyre et les papyrus. Quelques aspects de la vie municipale à la fin du IV et au début $d u V^{e}$ siècle, CE 66, 1991, p. 237sqq; P. FilipCZAK, Historia diakona Barochasa. Kilka uwag na temat niepokojów społecznych w miastach wczesnego Bizancjum, [in:] Byzantina Europaea. Ksiegga jubileuszowa ofiarowana Profesorowi Waldemarowi Ceranowi, ed. M. Koкoszko, M.J. LeszKa, Łódź 2007 [= BL, 11], p. 108-109.
} 
of the property owned by the Gaza bishopric breaks; it recurs, however, in the final part of The Life. Naturally, managing real estate assets entailed keeping in contact with pagan local officials (a fact stressed by Mark the Deacon). Due to the fact that, at the turn of the $5^{\text {th }}$ century $\mathrm{AD}$, the cities in the East still remained pagan for the most part, the relations between the local Christians and the pagan officials were quite strained. Judging by Mark the Deacon's account, in Gaza the relations worsened significantly after the local shrines had been demolished, which also testifies of the power of pagan communities in the early decades of the $5^{\text {th }}$ century $\mathrm{AD}$ in the East. Even when bereaved of their temples, the pagans still played an important role there, mostly in terms of economy. Around the year $420 \mathrm{AD}$ (as follows from Mark the Deacon's chronology), Gaza become a place of a dispute

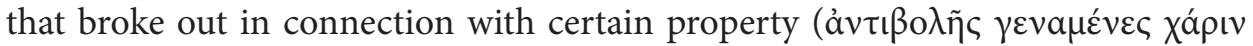
$\chi \omega p^{\prime}(\omega v)$ between an anonymous church steward and Sampsychos, one of the local officials ( $\pi \rho \omega \tau \varepsilon v ́ o v \tau \varepsilon \varsigma$ ) and a member of the city council. This disagreement likewise led to a brawl, which culminated in a pogrom of the local Christians ${ }^{14}$. The tensions in the city were eventually pacified by Claros, the governor of Palaestina Prima, who dispatched one of his officers accompanied by "a great army" ( $\mu \varepsilon \tau \grave{\alpha}$

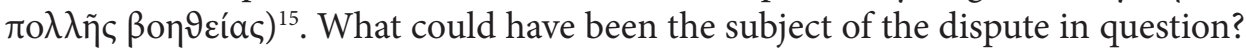
What, apart from religious matters (not mentioned by the author in this case), may have generated animosities between the local bishop and the decurions? I suppose that the conflict was in fact caused by financial issues - such as taxation burden, some unpaid obligations, or taking advantage of fiscal privileges on such occasions (these were allegedly bestowed on the bishopric of Gaza by empress Eudoxia; more on this below). If the account of the feud with Sampsychos were to be taken at face value, we should conclude that financial matters were the only factor at play here. If religious issues had been one of the causes, the author of the account would not have left this fact unmentioned, since he never does this in the other parts of his work (where, in fact, he widely describes the "persecutions" of Gaza Christians by the local pagans $\left.{ }^{16}\right)$.

\section{Cash reserves owned by the bishopric of Gaza at the beginning of the $5^{\text {th }}$ century}

In the Vita Porphyrii, we only find one piece of information concerning the topic in question, connected with an event dated to the early autumn of $403 \mathrm{AD}$. At that time, bishop Porphyry travelled to Palestinian Caesarea intending to resign from his office: as he claimed, he was not able to withstand the ever more aggressive actions on the part of the pagans. The tone used in the narrative is somewhat

\footnotetext{
${ }^{14}$ A. Laniado, Recherches sur les notables municipaux dans l'Empire protobyzantin, Paris 2002 [= TM.M, 13], p. 202sqq.

${ }^{15}$ Marcus Diaconus, Vita Porphyrii, 99. Cf. also P. Filipczak, Historia..., p. 115sqq.

${ }^{16}$ Cf. also P. FilipCzaK, Historia..., p. 119.
} 
dramatic, yet it may well reflect the actual problems concerning the relations with pagans in Gaza. The latter group still constituted a numerous and economically superior community, which drew its wealth mainly from wine trade, as confirmed not only by the accounts of Mark $^{17}$ but also by archaeological finds from early Byzantine Gaza ${ }^{18}$. In Caesarea, the decision is reached for bishop Porphyry not to step down from his post yet, but to go to the capital city of Constantinople together with his metropolitan. The power of paganism in Gaza was considered to be rooted in the temples - and rightly so, as those were not only places of pagan cult (including a renowned oracle in the temple of Zeus Marnas, also called the "lord of the rains" - $\kappa v ́ \rho ı \varsigma \tau \tilde{\omega} v$ ö $\mu \beta \rho \omega v)^{19}$, but first and foremost an economic supply base. In the latter capacity, they had grown and developed for centuries, although Mark the Deacon does not utter a single word on this aspect. If the temples were to be destroyed, their assets would be liquidated as well-probably quite arbitrarily, yet the local Church would nevertheless certainly be one of the beneficiaries in such a case ${ }^{20}$. Undoubtedly, the economic supply base was also an important element of Christianisation.

\footnotetext{
${ }^{17}$ Marcus Diaconus, Vita Porphyrii, 20.

${ }^{18}$ W.J. Hopkins, The City Region in Roman Palestine, PEQ 112, 1980, p. 19; P. Mayerson, The Wine and Vineyards of Gaza in the Byzantine Period, BASOR 257, 1985, p. 75-80; B. JoHnson, L. STAGER, Ashkelon: Wine Emporium of the Holy Land, [in:] Recent Excavations in Israel. A View to the West. Reports on Kabri, Nami, Miqne-Ekron, Dor and Ashkelon, ed. S. Gitin, Dubuque 1995, p. 95-109; Y. Tsafrir, The Fate of Pagan Cult Places in Palestine. The Archeological Evidence with Emphasis on Beth Shean, [in:] Religious and Ethnic Communities in Later Roman Palestine, ed. H. LAPIN, Potomac 1998 [= STJHC, 5], p. 202-204; S.A. KIngSLEY, The Economic Impact of the Palestinian Wine Trade in Late Antiquity, [in:] Economy and Exchange in the East Mediterranean during Late Antiquity. Proceedings of a Conference at College (Oxford, $29^{\text {th }}$ May 1999), ed. S.A. Kingsley, M. Decker, Oxford 2001, p. 44; L. SEgni, The Territory..., p. 41sqq.

${ }^{19}$ Zeus Marnas was the Hellenistic incarnation of Dagon, the local god and patron of agriculture, cf. J. Straub, Marnas, [in:] Historia-Augusta-Colloquium, Bonn 1963, ed. IDem, Bonn 1964 [= Ant, 4; BHAF, 2], p. 165-170; P. Chuvin, Chronique des derniers païens. La disparition du paganisme dans l'Empire romain, du règne de Constantin a celui de Justinien, Paris 1990, p. 64sqq; N. Belayche, Iudaea-Palaestina. The Pagan Cults in Roman Palestine (Second to Fourth Century), Tübingen 2001 [= RRP, 1], p. 232-256.

${ }^{20}$ On the confiscation of the property of pagan temples see: A. Frantz, From Paganism to Christianity in the Temples of Athens, DOP 19, 1965, p. 201sqq; F. ThÉlamon, Païens et Chrétiens au IV siècle. L'apport de Histoire ecclésiastique de Rufin de Aquilée, Paris 1981, p. 255sqq; C. Foss, Ankyra, [in:] RAC, vol. I, Supplement, p. 458-459; H. SARAdi-MendelovicI, Christian Attitudes toward Pagan Monuments in Late Antiquity and Their Legacy in Later Byzantine Centuries, DOP 44, 1990, p. 53sqq; P. Thrams, Christianisierung des Römerreiches und heidnischer Widerstand, Heidelberg 1992, p. 114-116sqq; P. Grossmann, Tempel als Ort des Konflikts in christlicher Zeit, [in:] Le temple, lieu de conflit. Actes du colloque de Cartigny, 1991, ed. P. Borgeaud et al., Leuven 1995, p. 181sqq; C. HaAs, Alexandria in Late Antiquity. Topography and Social Conflicts, Baltimore-London 1997 [= ASH], p. 146sqq; J. HaHn, Tempelzerstörung und Tempelreinigung, [in:] Kult, Konflikt, Sühne. Beiträge zur kultischen Sühne in religiösen, sozialen und politischen Auseinandersetzungen des antiken Mittelmeerraumes, ed. H. AlberTz, Münster 2001, p. 272-282.
} 


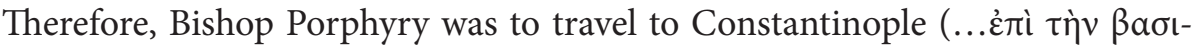

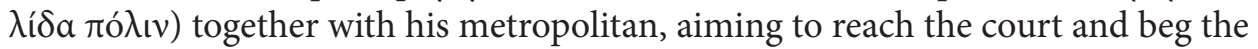
emperors (...iva $\delta \varepsilon \eta 9 \tilde{\omega} \mu \varepsilon v \tau \tilde{\omega} v \beta a \sigma i \lambda \varepsilon \dot{\varepsilon} \omega v)$ to allow him to demolish the shrines

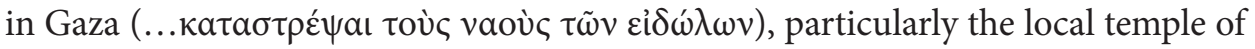
Zeus (the so-called Marneion). The idea was not ungrounded, after all, and it was hoped that John - the bishop of the capital - would help ${ }^{21}$. If the two priests had not had at least a shred of hope of reaching the court, the whole trip would have been pointless. When summoned to Caesarea, Mark, the deacon of the church

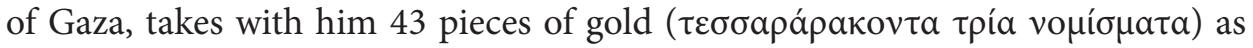

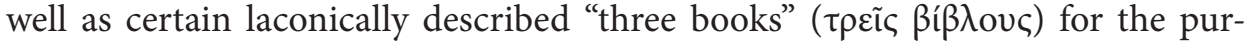
pose of the trip, thus emptying the bishopric's treasury ${ }^{22}$. The books do not appear in the later part of the account, yet it may be presumed that they were volumes of the Scripture, or even the Gospels only (most probably codices, more convenient in use and transport than scrolls). Why would as many as three volumes be taken, then? There can only be one explanation: they were to be sold to help cover the expenses of the travel and stay in Constantinople. An analogical case is known from another work of hagiography completed in Palestine during the second half of the $4^{\text {th }}$ century $\mathrm{AD}$. The text in question is The Life of Hilarion, where the protagonist, as Hieronymus claims, sold a volume of the Gospel that he owned in order to pay for his sea voyage from Africa to Sicily. We are not told whether it was the whole set of the canonical Gospels or just one of them ${ }^{23}$.

If the assumption concerning the aforementioned books is valid, how much could they be worth? If a volume was not made in a particularly exquisite fashion, its value may have reached the sum of 20 solidi per piece. Such a price is stated by the author of one of the Apophthegmata Patrum ${ }^{24}$. In the case at hand, however, there is no information regarding the value of the codex put on sale, the quality of its making, or the condition in which it was preserved. Let us now return to the account, according to which Mark was ordered to deliver the cash as well as the aforementioned "three books" from the church treasury to Caesarea. It would follow that the bishopric of Gaza at the end of $403 \mathrm{AD}$ (October or November, as the beginning of Porphyry's journey to Constantinople is dated to that time) only had very modest means at its disposal, given that the cash and objects taken to be

${ }^{21}$ Cf. G. Dagron, Naissance d'une capitale. Constantinople et ses institutions de 330 a 451, Paris 1974 [= BBE, 7], p. 498-504; IDEM, Le christianisme dans la ville byzantine, DOP 31, 1977, p. 8-9; F. vAN Ommeslaeghe, Jean Chrysostome en conflict avec l'imperatrice Eudoxie. Le dossier et les origines d'une légende, AB 97, 1979, p. 131sqq; K.G. Holum, Theodosian..., p. 70-78; C. Tiersch, Johannes Chrysostomus in Konstantinopel (398-404). Weltsicht und Wirken eines Bischofs in der Hauptstadt des Oströmischen Reiches, Tübingen 2002 [= STAC, 6], p. 327-378.

${ }^{22}$ Marcus Diaconus, Vita Porphyrii, 34.

${ }^{23}$ Cf. Hieronymus, Vita Hilarionis, 35-36, [in:] PL, vol. XXIII, col. 47.

${ }^{24}$ Cf. Apophthegmata Patrum. De abbate Gelasio, [in:] PG, vol. LXV, col. 145-146, where the prices

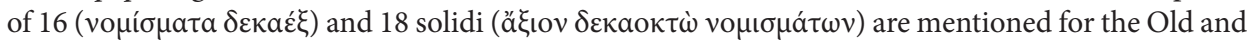
New Testament codices, respectively. 
sold would have been worth a total of ca. 100 solidi $^{25}$. We may note that the money that Porphyry had come into from his inheritance in Thessaloniki totalled 4400 solidi, while the valuables cashed in Jerusalem totalled 1400 solidi $^{26}$. This money was spent on charitable causes.

\section{Charitable activities of the bishopric of Gaza}

The information on the charity work conducted during the period of bishop Porphyry's rule gives us certain insight into the wealth of the church of Gaza at the time. The first relevant piece of information is the record of the alms amounting to

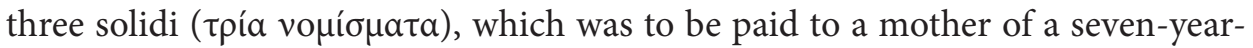
old boy who, as a medium, communicated God's will to the Christians of Gaza concerning the local temple of Zeus ${ }^{27}$. Further information concerning the alms distributed by the bishopric of Gaza only appears at one more spot in our text - when the circumstances of the consecration of the Eudoxiane, a basilica erected at the site of the destroyed Marneion ${ }^{28}$, are described. According to the Mark the Deacon's account, bishop Porphyry spent generous amounts on this purpose and ordered to give out alms ${ }^{29}$. The narrative mentions donations totalling from 6 to 10 obols $^{30}$. In order to cover these expenses, Porphyry assigned a certain sum from the income of the bishopric of Gaza. However, he highlighted that if for whatever reason the money was not distributed in Gaza, it should be spent on supporting the poor in Palestinian Caesarea ${ }^{31}$.

In addition, another piece of information - laconic as it may be - sheds some light on the financial situation of the Gaza bishopric around $420 \mathrm{AD}$. It seems that bishop Porphyry, intending to return the favour to certain women who had helped him by providing shelter during the pogrom of Christians in the city, ordered to pay them financial gratifications. A woman named Salaphta and her grandmother were to receive 4 solidi each, daily, for an indefinite amount of time, whereas her aunt was to be given a single payment of 1 solidus $^{32}$. The information is not too clear, not least as regards the amounts cited. If valid, the latter would indicate that the economic condition of the bishopric of Gaza towards the end of Porphyry's rule was at least fairly good.

\footnotetext{
${ }^{25}$ Marcus Diaconus, Vita Porphyrii, 34.

${ }^{26}$ Marcus Diaconus, Vita Porphyrii, 6, 9.

${ }^{27}$ Marcus Diaconus, Vita Porphyrii, 68. p. 2412sqq. The financial means for this purpose were transferred to bishop Porphyry by empress Aelia Eudoxia. cf. Marcus Diaconus, Vita Porphyrii, 53.

${ }^{29}$ Marcus Diaconus, Vita Porphyrii, 92.

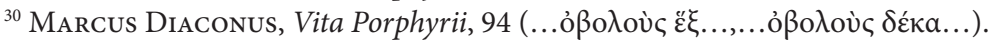

${ }^{31}$ Marcus Diaconus, Vita Porphyrii, 94.

${ }^{32}$ Marcus Diaconus, Vita Porphyrii, 100.
}

${ }^{28}$ J. Straub, Marnas..., p. 165sqq; G. Mussies, Marnas God of Gaza, [in:] ANRW, vol. XVIII.4, 


\section{Endowments of the imperial court to the bishopric of Gaza}

It is difficult to assess the validity of the account concerning one of the main themes of The Life - i.e. Porphyry's journey to Constantinople, including the endowments he received there (the latter being a crucial issue from the point of view of our inquiry). Similarly, it is unclear what we should make of the poorly described fiscal privileges mentioned there, which - we may presume - must have had a significant influence on the economic situation of the church of Gaza in the times of bishop Porphyry and after his death ${ }^{33}$. The essential question is, however, whether the donations by empress Eudoxia and her husband, emperor Arcadius, really took place. Since hagiographic texts are infamously unreliable on issues such as this, it is difficult to settle the case unequivocally. Firstly, we may ask whether such a journey was even possible to undertake in the first place. It probably was, it would seem, considering the fact that the bishops would travel to Constantinople convinced of support from the local bishop John (a fact conspicuously emphasized by Mark the Deacon $)^{34}$. Secondly, is it conceivable that blatantly false information concerning such an important journey might have been included in the narrative - the more so that it had such a crucial meaning for the development of later events? Let us recall that the story culminates in the destruction of the shrines in Gaza, including the Marneion, at whose location a luxurious basilica was erected and named after empress Eudoxia. The latter circumstance, in particular, seems to confirm the validity of Mark the Deacon's account. All the same, it does not mean that one should necessarily embrace all of the details found in it, including the description of how the Palestinian bishops were received at the court and what donations they received on these occasions. If the story is true, such donations must have indeed occurred (the generosity of Arcadius and Aelia Eudoxia towards those who were allowed to appear before their imperial majesties was obvious), yet perhaps not in the amounts cited by Mark the Deacon. The bishopric of Gaza, which had no more than 43 pieces of gold in its treasury in $403 \mathrm{AD}$, could not have afforded to build a lavish basilica of the kind that Mark describes. We must bear in mind that the text, even if it was not created shortly after the demise of bishop Porphyry (as Mark the Deacon assures us), could not have contained a distortion in a matter as important as the imperial court's financing the construction of the

\footnotetext{
${ }^{33}$ Cf. among others G. Dagron, Naissance..., p. 498-504; F. Van Ommeslaeghe, Jean ..., p. 131sqq; K.G. Holum, Theodosian..., p. 70sqq; A. McClanan, Representations of Early Byzantine Empresses. Image and Empire, New York-Basingstoke 2002, p. 19-20; C. Tiersch, Johannes..., p. 327sqq; M. Kahlos, Forbearance and Compulsion. The Rhetoric of Religious Tolerance and Intolerance in Late Antiquity, London 2009, p. 134.

${ }^{34}$ J.N.D. Kelly, Golden Mouth. The Story of John Chrysostom - Ascetic, Preacher, Bishop, London 1995, p. 140-141; P. VAn Nuffelen, Playing the Ritual Game in Constantinople under the Theodosian Dynasty (379-457), [in:] Two Romes. From Rome to Constantinople, ed. L. Grig, G. Kelly, Oxford 2012, p. 190-196.
} 
basilica (although we know that the empress died several months after Porphyry had left Constantinople ${ }^{35}$ ). Thus, the account may well have been embellished or even distorted regarding certain points. Nevertheless, the essential part of the message still remains credible: the existence of an exquisite basilica in the centre of Gaza has been confirmed not only by the aforementioned accounts as well as the depictions in the mosaics of Madaba ${ }^{36}$, but also by an accidental discovery made at the beginning of April 2016 in $\mathrm{Gaza}^{37}$. The latter proves that a majestic church or basilica once stood within the early Byzantine limits of the city. In the published photographs from the site of the discovery, one may see not only a huge column capital bearing the sign of a cross ( 90 centimetres in height), but also at least two impressive columns, shattered and perhaps duly left at the spot where the demolished basilica once stood. As far as I know, there is no unequivocal confirmation of the fact that we are indeed dealing with the basilica described by Mark, yet it is certainly a temple dating back to the early Byzantine period, and it appears to be the one depicted in the mosaics of Madaba. The author of the mosaic - or rather the person who ordered and funded it - evidently considered the grand building as a symbol of the city (in the period in question, this was the key according to which motifs or buildings to be included in mosaics were chosen).

However, let us return to Porphyry's journey to Constantinople, the main goal of which was to reach the imperial court and obtain the permission to demolish the pagan temples in Gaza. Mark the Deacon claims that, during a series of audiences, bishop Porphyry was able to secure great amounts of gold from the imperial couple. Besides a total of 200 solidi to cover the expenses during the stay in Constantinople $\mathrm{e}^{38}$, Porphyry received significant amounts for the needs of his bishopric as well as the planned construction. Porphyry received two kentenaria of gold ( $\delta$ v́o

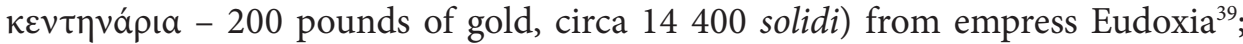
he also obtained an unidentified sum for building a ksendodocheion in Gaza ${ }^{40}$. In addition, emperor Arcadius endowed the sum of 20 pounds of gold ( $\chi \rho v \sigma o \tilde{v}$

\footnotetext{
${ }^{35}$ O. SeEcK, Eudoxia, [in:] RE, vol. VI.1, col. 926.

${ }^{36}$ M. Avi-Yonah, The Madaba Mosaic Map with Introduction and Commentary, Jerusalem 1954, p. 72, an. 101; M. Piccirillo, Mosaics of Jordan, ed. P.M. BikAi, T.A. DAiley, Amman 1992 [= ACORP, 1], p. 227, 232. Cf. also G. Downey, Gaza in the Early Sixth Century, Norman 1963, p. 17; C.A.M. Glucker, The City of Gaza in the Roman and Byzantine Periods, Oxford 1987, p. 48sqq; G. Mussies, Marnas..., 2418; L. Ryden, Gaza, Emesa, and Constantinople, [in:] Aspects of Late Antiquity and Early Byzantium. Papers Read at a Colloquium Held at the Swedish Research Institute in Istanbul, 31 May - 5 June 1992, ed. L. Rydén, J.O. RosenQvist, Stockholm 1993, p. 133-137.

${ }^{37} \mathrm{Cf}$. the local press reports: www.mostresource.org/storybank/ruins-byzantine-church-discoveredgaza and www.ekalexandria.org/en/2016/04/22/workers-find-remnants-byzantine-church-gaza/\#. WlqwWHmzXDc [19 V 2018].

${ }^{38}$ Marcus Diaconus, Vita Porphyrii, 41, 54. Cf. also C. Tiersch, Johannes..., p. 206sqq.

${ }^{39}$ C. Morrisson, G. Dagron, Le Kentènarion dans les sources byzantines, RN 17, 1975, p. 157sqq; J.-P. CAllu, Le "centenarium" et l'enrichissement monétaire au Bas-Empire, Kt 3, 1978, p. 305-306.

${ }^{40}$ Marcus Diaconus, Vita Porphyrii, 53.
} 


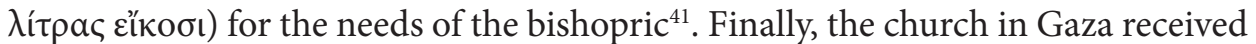

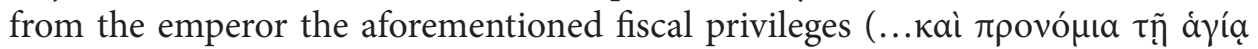

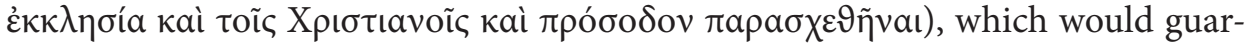
antee its economic development in the forthcoming decades ${ }^{42}$.

$$
* * *
$$

To conclude, what can be said of the financial standing of the church of Gaza in the years 395-420 AD, during the rule of bishop Porphyry? In spite of the scarcity of the relevant data, we do gain some insight into the financial standing of the bishopric. In comparison to analogical accounts concerning other bishoprics in the Eastern provinces of the Empire in late Antiquity, we may in fact speak of an abundance of information, as in most cases the data are still more sparse or nonexistent at all. Outside of Egypt, it is hard to find a case better documented than the one under discussion. To be sure, we do have certain accounts concerning the church in Ephesus at the turn of the $5^{\text {th }}$ century AD, yet that information relates to the personal wealth of the corrupt bishop Antoninos (who mostly acquired it through practising simony) ${ }^{43}$. A similar case is that of Nazianzos (in Cappadocia) under Gregory's rule: this bishop's Testament, although a valuable source of information on the monetary history of late Antiquity, only refers to his personal wealth ${ }^{44}$. The rich legacy of the Cappadocian Fathers of the Church furnishes little information concerning the economic state of the bishoprics they managed. We may note that - according to Mark the Deacon - bishop Porphyry owned private property towards the end of his life; he acquired it during his tenure in Gaza. Let us recall that he came to the city without a dime in his pocket (all cash reserves, inheritance, and other assets had been given out to support the poor in Jerusalem), while his last will is described by Mark as "bequeathing gifts to many"

Surprising as it may seem, even as regards churches such as those of Antioch ${ }^{46}$ or Constantinople ${ }^{47}$, little is known about their wealth at the turn of the $5^{\text {th }}$ century $\mathrm{AD}$. In most cases (save for the several statements by John Chrysostom, Palladius of Helenopolis ${ }^{48}$, and the anonymous author of the Vita Olym-

\footnotetext{
${ }^{41}$ Marcus Diaconus, Vita Porphyrii, 54.

${ }^{42}$ Marcus Diaconus, Vita Porphyrii, 46, 48-50.

${ }^{43}$ Cf. J.N.D. Kelly, Golden..., 172-180; H. Willer LaAle, Ephesus (Ephesos). An Abbreviated History from Androclus to Constantine XI, Bloomington 2011, p. 304-306; P. Whiтworth, Constantinople to Chalcedon. Shaping the World to Come, Durham 2017, p. 82-83.

${ }^{44}$ Cf. J. Beaucamp, Le Testament de Grégoire de Nazianze, [in:] Fontes minores, X, ed. L. Burgmann, Frankfurt am Main 1998 [= FBR, 22], p. 1-100.

${ }^{45}$ Marcus Diaconus, Vita Porphyrii, 103.

${ }^{46}$ J.N.D. Kelly, Golden..., p. 55sqq.

${ }^{47}$ Cf. G. Dagron, Naissance..., p. 496-509.

${ }^{48}$ Palladios, Dialogue sur la vie de Jean Chrysostome, XVII, 141-147, vol. II, ed. A.-M. MalinGREY, Paris 1988 [= SC, 342], p. 170; The Lausiac History of Palladius, LVI, 2, vol. II, The Greek Text, ed. C. Butler, Cambridge 1904, p. 150.
} 
piadis ${ }^{49}$ ), we are dealing with bare estimates; the main gauge that allows to appraise the financial standing of these churches is the information on the charity work undertaken there (usually with no specific figures cited).

Consequently, the data presented above - albeit admittedly scanty - are still quite remarkable when compared with those from other churches in the Eastern provinces of the early Byzantine period. Undeniably, it seems justified to treat at least some of the amounts cited in the Vita Porphyrii as reflecting particular topoi (especially when we hear of three solidi, three handfuls of solidi, or the sums of 100 and 1000 solidi $^{50}$ ); nevertheless, the source under analysis greatly enhances our knowledge of the wealth of the Church as well as its functions in the early Byzantine period.

\section{Bibliography}

\section{Primary Sources}

Apophthegmata Patrum, [in:] Patrologiae cursus completus, Series graeca, vol. LXV, ed. J.-P. Migne, Paris 1858, col. 71-442.

La conversion de Gaza au christianisme. La Vie de S. Porphyre de Gaza par Marc le Diacre (BHG 1570), ed. et trans. A. Lampadaridi, Bruxelles 2016 [= Subsidia hagiographica, 95].

Hieronymus, Vita Hilarionis, [in:] Patrologiae cursus completus, Series latina, vol. XXIII, ed. J.-P. Migne, Paris 1865, col. 29-54.

The Lausiac History of Palladius, vol. II, The Greek Text, ed. C. ButLer, Cambridge 1904.

Marc le Diacre, Vie de Porphyre, évêque de Gaza, trans. H. Grégoire, M.-A. Kugener, Paris 1930 [= Collection byzantine $]$.

Marcus Diaconus, Vita Sancti Porphyrii = Leben des heiligen Porphyrius, trans. A. HüBner, Freiburg im Breisgau 2013 [= Fontes Christiani, 53].

\footnotetext{
${ }^{49}$ Vita Olympiadis, V, 21-33; VII, 3-4, [in:] Jean Chrysostome, Lettres à Olympias; La Vie anonyme d'Olympias, trans. A.-M. Malingrey, ${ }^{2}$ Paris 1968 [= SC, 13bis], p. 418-420. Cf. also C. Broc, Le role des femmes dans l'Église de Constantinople d'apres la correspondance de Jean Chrysostome, [in:] SP, vol. XXVII, p. 151sqq; E.M. SYNeK, Heilige Frauen der frühen Christenheit. Zu den Frauenbildern in hagiographischen Texten des christlichen Ostens, Würzburg 1994 [= OC.NF, 43], p. 175-181; W. Meyer, Constantinopolitan Women in Chrysostom's Circle, VC 53, 1999, p. 267sqq; M. Heine, Die Spiritualität von Asketinnen. Von den Wüstenmüttern zum städtischen Asketinnentum im östlichen Mittelmeerraum und in Rom vom 3. bis zum 5. Jahrhundert, Berlin 2008, p. 109-110.

${ }^{50}$ For some remarks on digits and numbers quoted in ancient Greek literature cf. R. MehrleIn, Drei, [in:] RAC, vol. IV, p. 269sqq; D. Fenling, Die Quellenangaben bei Herodot. Studien zur Erzählkunst Herodots, Berlin-New York 1971 [= ULG, 9], p. 155-167; K. Ruffing, 300, [in:] Herodots Quellen - die Quellen Herodots, ed. B. Dunsch, K. Ruffing, Wiesbaden 2013, p. 201sqq. On numbers in early Byzantine hagiography cf. P. Devos, Les nombres dans l'Historia monachorum in Aegypto, AB 92, 1974, p. 97-108.
} 
Palladios, Dialogue sur la vie de Jean Chrysostome, vol. I-II, ed. A.-M. Malingrey, Paris 1988 [= Sources chrétiennes, 341-342].

Vita Olympiadis, [in:] JeAn Chrysostome, Lettres à Olympias; La Vie anonyme d'Olympias, trans. A.-M. Malingrey, ${ }^{2}$ Paris 1968 [= Sources chrétiennes, 13bis], p. 406-449.

\section{Secondary Literature}

Avi-Yonah M., The Madaba Mosaic Map with Introduction and Commentary, Jerusalem 1954.

Bagnal R., Egypt in Late Antiquity, Princeton 1995.

Barnes T.D., Early Christian Hagiography and Roman History, Tübingen 2010.

Beaucamp J., Le Testament de Grégoire de Nazianze, [in:] Fontes minores, X, ed. L. Burgmann, Frankfurt am Main 1998 [= Forschungen zur Byzantinischen Rechtsgeschichte, 22], p. 1-100.

Belayche N., Iudaea-Palaestina. The Pagan Cults in Roman Palestine (Second to Fourth Century), Tübingen 2001 [= Religions in the Roman provinces = Religion der römischen Provinzen, 1].

Blume M., La Vie de Porphyre et les papyrus. Quelques aspects de la vie municipale à la fin du $I V^{e}$ et au début du Vé siècle, "Chronique d'Égypte" 66, 1991, p. 237-244.

BRoc C., Le role des femmes dans l'Église de Constantinople d'apres la correspondance de Jean Chrysostome, [in:] Studia Patristica, vol. XXVII, Papers Presented at the Eleventh International Conference on Patristic Studies Held in Oxford 1991, ed. E.A. Livingstone, Leuven 1993, p. 150-154.

Broshi M., The Population of Western Palestine in the Roman-Byzantine Period, "Bulletin of the American Schools of Oriental Research in Jerusalem and Baghdad" 236, 1979, p. 1-10.

CAllu J.P., Le "centenarium" et l'enrichissement monétaire au Bas-Empire, "Ktema. Civilisation de l'Orient, Grèce et Rome Antiques" 3, 1978, p. 121-136.

Chuvin P., Chronique des derniers païens. La disparition du paganisme dans l'Empire romain, du règne de Constantin a celui de Justinien, Paris 1990.

Čechanovec Ja.M., Marnas victus est a Christo. K voprosu o christianizacii drevnej Gazy, [in:] MNEMON. Issledovanija i publikacii po istorii antičnogo mira, V, ed. Z.D. Frolov, Sankt-Peterburg 2006, p. 419-454.

Dagron G., Le christianisme dans la ville byzantine, "Dumbarton Oaks Papers" 31, 1977, p. 3-25.

Dagron G., Naissance d'une capitale. Constantinople et ses institutions de 330 a 451, Paris 1974 [= Bibliothèque byzantine. Études, 7].

Devos P., Les nombres dans l'Historia monachorum in Aegypto, "Analecta Bollandiana" 92, 1974, p. $97-108$.

Downey G., Gaza in the Early Sixth Century, Norman 1963.

FeHLing D., Die Quellenangaben bei Herodot. Studien zur Erzählkunst Herodots, Berlin-New York 1971 [= Untersuchungen zur antiken Literatur und Geschichte, 9].

FilipCZAK P., Historia diakona Barochasa. Kilka uwag na temat niepokojów społecznych w miastach wczesnego Bizancjum, [in:] Byzantina Europaea. Ksiega jubileuszowa ofiarowana Profesorowi Waldemarowi Ceranowi, ed. M. Кокоszко, M.J. LeszkA, Łódź 2007 [= Byzantina Lodziensia, 11], p. 107-120.

Foss C., Ankyra, [in:] Reallexikon für Antike und Christentum, vol. I, Supplement, ed. E. Dassmann et al., Stuttgart 1985, p. 448-465.

Fowden G., Bishops and Temples in the Eastern Roman Empire AD 320-435, "The Journal of Theological Studies" 29, 1978, p. 53-78. 
Frantz A., From Paganism to Christianity in the Temples of Athens, "Dumbarton Oaks Papers" 19, 1965, p. 187-205.

GAscou J., Les grands domaines, la cité et l'état en Egypte byzantine. (Recherches d'histoire agraire, fiscale et administrative), "Travaux et mémoires du Centre de recherches d'histoire et civilisation byzantines" 9, 1985, p. 1-90.

Glucker C.A.M., The City of Gaza in the Roman and Byzantine Periods, Oxford 1987.

Grossmann P., Tempel als Ort des Konflikts in christlicher Zeit, [in:] Le temple, lieu de conflit. Actes du colloque de Cartigny, 1991, ed. P. Borgeaud et al., Leuven 1995, p. 181-201.

HaAs C., Alexandria in Late Antiquity. Topography and Social Conflicts, Baltimore-London 1997 [= Ancient Society and History].

Hahn J., Gewalt und religiöser Konflikt. Studien zu den Auseinandersetzungen zwischen Christen, Heiden und Juden im Osten des Römischen Reiches (von Konstantin bis Theodosius II.), Berlin 2004.

HaHn J., Die Herausforderung der antiken Stadt in der Spätantike - Christentum, urbane Sakraltopographie und religiöse Gewalt, [in:] Pluralität. Konkurrenz. Konflikt Religiöse Spannungen im städtischen Raum der Vormoderne, ed. J. OвеRste, Regensburg 2013 [= Forum Mittelalter. Studien, 8], p. 11-30.

Hahn J., Tempelzerstörung und Tempelreinigung, [in:] Kult, Konflikt, Sühne. Beiträge zur kultischen Sühne in religiösen, sozialen und politischen Auseinandersetzungen des antiken Mittelmeerraumes, ed. H. Albertz, Münster 2001, p. 269-285.

Heine M., Die Spiritualität von Asketinnen. Von den Wüstenmüttern zum städtischen Asketinnentum im östlichen Mittelmeerraum und in Rom vom 3. bis zum 5. Jahrhundert, Berlin 2008.

Holum K.G., Theodosian Empresses. Women and Imperial Dominion in Late Antiquity, BerkeleyLondon 1982.

Hopkins W.J., The City Region in Roman Palestine, "Palestine Exploration Quarterly" 112, 1980, p. 19-32.

Johnson B., Stager L., Ashkelon: Wine Emporium of the Holy Land, [in:] Recent Excavations in Israel. A View to the West. Reports on Kabri, Nami, Miqne-Ekron, Dor and Ashkelon, ed. S. Gitin, Dubuque 1995, p. 95-109.

Jones A.H.M., The Later Roman Empire, 284-602. A Social, Economic and Administrative Survey, vol. II, Oxford 1964.

Kahlos M., Forbearance and Compulsion. The Rhetoric of Religious Tolerance and Intolerance in Late Antiquity, London 2009.

Kelly J.N.D., Golden Mouth. The Story of John Chrysostom - Ascetic, Preacher, Bishop, London 1995.

Kingsley S.A., The Economic Impact of the Palestinian Wine Trade in Late Antiquity, [in:] Economy and Exchange in the East Mediterranean during Late Antiquity. Proceedings of a Conference at Somerville College (Oxford, $29^{\text {th }}$ May 1999), ed. S.A. Kingsley, M. Decker, Oxford 2001, p. $44-68$.

LaAle H.W., Ephesus (Ephesos). An Abbreviated History from Androclus to Constantine XI, Bloomington 2011.

LANiado A., Recherches sur les notables municipaux dans l'Empire protobyzantin [= Travaux et mémoires du Centre de recherche d'histoire et civilisation de Byzance, Collège de France. Monographies, 13], Paris 2002. 
Mayerson P., Justinians's Novella 103 and the Reorganisation of Palestine, "Bulletin of the American Schools of Oriental Research in Jerusalem and Baghdad” 269, 1988, p. 65-71.

Mayerson P., The Wine and Vineyards of Gaza in the Byzantine Period, "Bulletin of the American Schools of Oriental Research in Jerusalem and Baghdad” 257, 1985, p. 75-80.

McClanan A., Representations of Early Byzantine Empresses. Image and Empire, New York-Basingstoke 2002.

Mehrlein R., Drei, [in:] Reallexikon für Antike und Christentum, vol. IV, ed. E. Dassmann, Stuttgart 1959, p. 269-310.

Meyer W., Constantinopolitan Women in Chrysostom's Circle, "Vigiliae Christianae" 53, 1999, p. 265-288.

Morrisson C., Dagron G., Le Kentènarion dans les sources byzantines, "Revue numismatique" 17, 1975 , p. $145-162$.

Mussies G., Marnas God of Gaza, [in:] Aufstieg und Niedergang der römischen Welt. Geschichte und Kultur Roms im Spiegel der neueren Forschung, T. II, Principat, vol. XVIII.4, ed. H. TemporinI, W. HaAse, New York-Berlin 1990, p. 2412-2457.

Nicholson O., Durmaz R., Porphyry of Gaza, [in:] The Oxford Dictionary of Late Antiquity, vol. II, ed. O. Nicholson, Oxford 2018, p. 1211.

Nuffelen P. VAn, Playing the Ritual Game in Constantinople under the Theodosian Dynasty (379-457), [in:] Two Romes. From Rome to Constantinople, ed. L. GRIG, G. Kelly, Oxford 2012, p. $183-200$.

Ommeslaeghe F. van, Jean Chrysostome en conflict avec l'imperatrice Eudoxie. Le dossier et les origines d’une légende, "Analecta Bollandiana" 97, 1979, p. 131-159.

Peeters P., La vie géorgienne de saint Porphyre de Gaza, "Analecta Bollandiana" 59, 1941, p. 165-216.

Piccirillo M., Mosaics of Jordan, ed. P.M. Bikai, T.A. Dailey, Amman 1992 [= American Center of Oriental Research Publications, 1].

Rapp C., Mark the Deacon, Life of St. Porphyry of Gaza, [in:] Medieval Hagiography. An Anthology, ed. T. Head, New York-London 2001, p. 53-75.

Ruffing K., 300, [in:] Herodots Quellen - die Quellen Herodots, ed. B. Dunsch, K. Ruffing, Wiesbaden 2013, p. 201-221.

Ryden L., Gaza, Emesa, and Constantinople, [in:] Aspects of Late Antiquity and Early Byzantium. Papers Read at a Colloquium Held at the Swedish Research Institute in Istanbul, 31 May - 5 June 1992, ed. L. Rydén, J.O. RosenQvist, Stockholm 1993, p. 133-144.

Saradi-Mendelovici H., Christian Attitudes toward Pagan Monuments in Late Antiquity and Their Legacy in Later Byzantine Centuries, "Dumbarton Oaks Papers" 44, 1990, p. 47-61.

Seeck O., Eudoxia, [in:] Paulys Real-Encyclopädie der classischen Altertumswissenschaft, vol. VI.1, ed. G. Wissowa, W. Kroll, Stuttgart 1907, col. 917-926.

Segni L., The Territory of Gaza. Notes of Historical Geography, [in:] Christian Gaza in Late Antiquity, ed. B. Bitton-Ashkelony, A. Kofsky, Leiden-Boston 2004 [= Jerusalem Studies in Religion and Culture, 3], p. 41-59.

Straub J., Marnas, [in:] Historia-Augusta-Colloquium, Bonn 1963, ed. J. Straub, Bonn 1964 [= Antiquitas, 4; Beiträge zur Historia-Augusta-Forschung, 2], p. 165-170.

Synex E.M., Heilige Frauen der frühen Christenheit. Zu den Frauenbildern in hagiographischen Texten des christlichen Ostens, Würzburg 1994 [= Das Östliche Christentum, Neue Folge, 43]. 
Thélamon F., Païens et Chrétiens au IV siècle. L'apport de Histoire ecclésiastique de Rufin de Aquilée, Paris 1981.

Thrams P., Christianisierung des Römerreiches und heidnischer Widerstand, Heidelberg 1992.

Tiersch C., Johannes Chrysostomus in Konstantinopel (398-404). Weltsicht und Wirken eines Bischofs in der Hauptstadt des Oströmischen Reiches, Tübingen 2002 [= Studien und Texte zu Antike und Christentum, 6].

Trombley F.R., Hellenic Religion and Christianization, c. 370-529, vol. I, Leiden-New York 1993.

Tsafrir Y., The Fate of Pagan Cult Places in Palestine. The Archeological Evidence with Emphasis on Beth Shean, [in:] Religious and Ethnic Communities in Later Roman Palestine, ed. H. LAPIN, Potomac 1998 [= Studies and Texts in Jewish History and Culture, 5], p. 197-218.

Whitworth P., Constantinople to Chalcedon. Shaping the World to Come, Durham 2017.

WipszycKa E., Les ressources et les activités économiques des églises en Égypte du IV a au VIII siècle, Bruxelles 1972 [= Papyrologica Bruxellensia, 10].

\begin{abstract}
The study attempts to determine the economic condition of a small provincial bishopric, namely the church of Gaza (Palestine) during the rule of bishop Porphyry (circa 395-420 AD). All of the information on the subject comes from the Vita Porphyrii by Mark the Deacon - a source whose historical value has often been disputed. Although the information on the wealth of the church in Gaza at the turn of the $4^{\text {th }}$ and $5^{\text {th }}$ centuries is not particularly vast or illuminating, it is nevertheless possible to identify several spheres of economic activity of the Gaza bishopric. These are, among other things, the property owned by the bishopric (real estate), its cash reserves (mostly at the beginning of the $5^{\text {th }}$ century), the endowments of the imperial court (given by emperor Arcadius and his wife, empress Aelia Eudoxia), as well as the charitable activity of the bishopric (especially on the occasion of erecting the Eudoxiane, probably in 407).
\end{abstract}

Keywords: early Byzantium, late Roman economy, early Byzantine hagiography, early Byzantine Church

Ireneusz Milewski

Uniwersytet Gdański

Wydział Historyczny

Instytut Historii

Zakład Historii Starożytnej

ul. Wita Stwosza 55

80-952 Gdańsk, Polska/Poland

hisim@univ.gda.pl 